\title{
Trends and Pattern of Sugarcane Production in Shahjahanpur District, Uttar Pradesh: A Geographical Analysis
}

\author{
Fazlur Rahman* and Nida Bee \\ Department of Geography, Aligarh Muslim University, Aligarh, Uttar Pradesh, India \\ "Corresponding author: fazlur.gayavi@gmail.com (ORCID ID: 0000-0001-7232-6155)
}

Received: $12-04-2019$

Revised: 17-07-2019

Accepted: 21-08-2019

\begin{abstract}
Sugarcane is important commercial crop of India. It is a major source of raw material for not only sugar industry but also other allied group of industries. Sugarcane plays a vital role for the overall socio-economic development of farming community. Uttar Pradesh is one of the leading producers of sugarcane in India. Shahjahanpur district of Uttar Pradesh has been selected as study area which is famous for sugarcane production. The main objectives of present paper are to assess the trends and patterns of sugarcane production in the district and explain the reasons behind the changes in the sugarcane production. The study is based on secondary sources of data. The study reveals that there is uneven trend of area under sugarcane as well as production of sugarcane in the district and it is found that government policies were important determinants for such trends. Jatipur and Dadrol blocks of the district show high concentration of sugarcane crop. The study further reflects that this area is experiencing an ongoing agricultural development pertaining to the sugarcane cultivation.

Highlights

(0 The study revealed uneven trend of both area as well as production of sugarcane in Shahjahanpur district.

- Sugarcane is most politically sensitive crop, any change in government policies has direct implication on sugarcane cropping.
\end{abstract}

Keywords: Sugarcane, uneven trends, production, concentration, instability, politically sensitive crop

India is a tropical monsoon country and climatic condition of India is most favourable for the sugarcane cultivation and therefore it is cultivated far and wide in the country. India is the second largest producer of sugarcane after Brazil which signifies that sugarcane is an important commercial crop of India. Sugarcane is the only raw material for all major sweeteners in the country. Sugarcane is versatile crop being a rich source of food, fiber, fuel, fodder and chemicals (Yadav et al. 2006). By products of sugarcane is also playing an important role for nation economy. Sugarcane production and its processing is a major source of employment and livelihood in India. About 50 million farmers and 3-5 lakhs skilled and unskilled workers are engaged in cultivation of sugarcane and sugar industries and its allied industries (Krishnakant et al. 2015). In India sugarcane is cultivated from Punjab to Kaniyakumri nevertheless Uttar Pradesh, Maharashtra, Tamil Nadu, Gujarat are major producers in India. India accounts about 18 percent of world's sugarcane production.

Uttar Pradesh is the largest producer of sugarcane in India. Sugarcane plays a vital role in the economy of the state and providing employment opportunities to large number of people. In Uttar Pradesh, the largest concentration of sugarcane areas are in the Upper Ganga-Yamuna Doab, Rohilkhand and TransSaryu areas which together produce about 70 per cent of the total sugarcane produced in the state. As many as 30 districts of the state produced sugarcane, 
$\underset{A \text { AESA }}{\int_{1}}$ Rahman and Nida Bee

however, Kheri, Muzaffarnagar, Meerut, Bijnor, Moradabad, Saharanpur, Bulandshahr, Bereilly, Shahjahanapur, Sitapur are the important sugarcane producing districts. Western Uttar Pradesh is considered as cane heart land of the state and socio economic condition of the western Uttar Pradesh is largely depend upon sugarcane production.

Western part of the state forms the core of sugarcane production in the country. For the improvement of sugarcane in north India, a sugar research station was established at Shahjahanpur in 1912 (Yadav et al. 2006). For the western Uttar Pradesh, sugarcane is so important that cane farmers has created a special niche among the farmer community of the area and famously called as Ganna Kisan (sugarcane farmer). Sugarcane is the only crop in western Uttar Pradesh which governs the regional politics of the Western Uttar Pradesh.

There are various problems faced by Ganna Kisan such as problem of low yield, low rate of recovery, high cost of cultivation, uneven production trend, old machinery etc. Unsatisfactory Government's pricing policies especially of sugarcane further aggravate the problem. Chandrashila and others (2017) examined that biggest problem of the Indian sugar industry is that it is one of the most politically sensitive commodities. Despite having a very small share in the monthly household budget, the slightest price increase can trigger inflation in other commodities. Perhaps the most remarkable impediment as par far as the sugarcane cropping is concerned that the production of sugarcane has increased significantly over the time but productivity remained stagnant (Uperti and Singh, 2017). Kishore and others (2017) analyzed that there are various stages in sugarcane cultivation each requires different machinery, though some machine has been developed for sugarcane crop worldwide but not adopted in India. Farmers have been largely using traditional methods. These results in low productivity, high cost of labour etc., they further suggested a proactive role of the governments to create awareness to adopts machinery and popularizing sugarcane equipments among the cane farmers. The effective financial management is the key to have the ultimate benefits of sugarcane farming to farmers (Mahajan et al. 2012). The main threats' facing by the cane farmer were area, production, yield and price risk (Saravanan et al.
2016). Thus, there is an urgent need to improve in productivity both in terms of yield as well as sugar contents and recovery by adopting better harvesting practices and close coordination of sugar mills with farmers (Yasmeen et al. 2018).

Ragnekar (1988) states that how sugarcane has emerged as one of the major agro industries in rural part of country during the past few decades. And there is fairly a strict government on sugarcane and its products, the industry faces many problems while receiving certain amount of protection from the government. Bulkiness, non-storability, post harvest deterioration, restricted buyers, governments high regulation are the limitation in sugarcane marketing which becomes entirely different from that of other crops (Yadav et al. 2006). Women are considered as invisible working hands in sugarcane farming, training to these women are crucial in order to strengthen the knowledge and technical know-how of the farm activities (Zaidi and Munir, 2014).

So the present study will examine the trends of production as well as area under sugarcane crop in the study area and it will also look at block wise trend of area under sugarcane production in the district. Since, stability in area, production, yield, and the prices of sugarcane is prerequisite for the holistic development of the region; the study will also try to highlight the main factors responsible for same.

\section{THE STUDY AREA}

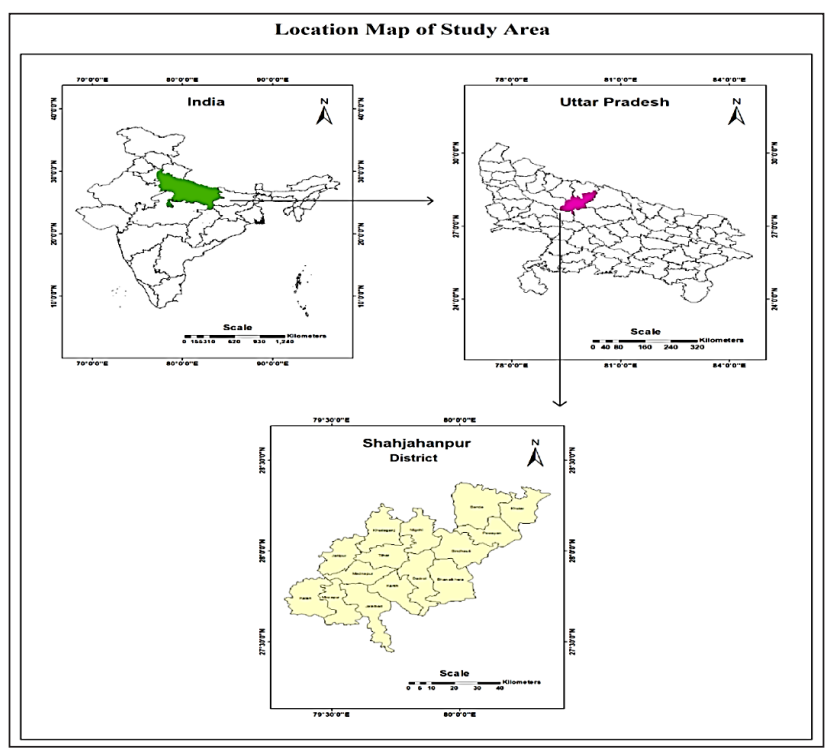

Fig. 1: Location Map of Study Area 
Shahjahanapur is a part of Bareilly division which is situated in south-east of Rohilkhand division. The district lies in $27^{\circ} 35^{\prime}$ to $28^{\circ} 29^{\prime} \mathrm{N}$ and $79^{\circ} 37^{\prime}$ to $80^{\circ} 23^{\prime} \mathrm{E}$. It is bounded by Kheri in the east, Hardoi and Farrukhabad in the south, Badaun and Bareilly in the west and Pilibhit in the north. The total area of the district is $4575 \mathrm{sq}$. $\mathrm{km}$ (Survey of India, 2011) and total population is 3006538 persons, according to 2011 census. The district has been divided into four tahsils (subdivisions) namely PowayanTilhar, Shahjahanpur, and Jalalabad. These tehsils are further subdivided into 15 community development blocks. The district consists of a narrow plain tract running from the Ganga river to the Himalayas. The region enjoys a tropical monsoon type climate. Major crops of the district are wheat, Sugarcane, Rice, Potato, etc.

\section{DATA BASE AND METHODOLOGY}

The present study is mainly based on secondary sources of data. The data were obtained from; District Statistical Handbook, Census of India, Sankhyakiya Patrika, Different Journals, Magazines, Articles, Books etc. The relevant data available on different websites were also incorporated in the study.

For showing the trends and pattern of area under sugarcane cultivation simple percentage method and different pictorial diagrams were used. All the maps of the study were prepared with the help of Arc GIS software. The sugarcane concentration in the blocks has been calculated through Bhatia's method. For the calculation of crop concentration the following formula has been employed;

$$
C_{x}=\frac{x / y}{x^{\prime} / y^{\prime}}
$$

Where,

$$
\begin{aligned}
& C_{x}=\text { Crop Concentration } \\
& x=\text { area of particular crop in the unit area } \\
& y=\text { total cropped area in the unit area } \\
& x^{\prime}=\text { area of particular crop in the region } \\
& y^{\prime}=\text { total cropped area in the region }
\end{aligned}
$$

For showing the growth in production of sugarcane from 1997-98 to 2016-17, Compound Annual Growth rate or CAGR method has been used. Compound annual growth rate is comparatively simple metric, it is the mean annual growth rate of an investment over a specific period of time. Formula for Calculating CAGR is;

$$
\mathrm{CAGR}=(\text { Ending Value/Beginning Value })^{(1 / \mathrm{n})}-1
$$

$n=$ Number of Periods (Months, Years etc.)

\section{RESULT AND DISCUSSION}

\section{Scenario of Sugarcane Production in Uttar Pradesh}

Uttar Pradesh is the largest producer of sugarcane in India. Uttar Pradesh alone produced 45 percent of total sugarcane in India (2016-2017). From table 1 and figure 2, it is clear that in Uttar Pradesh, sugarcane production is highly concentrated in Western Part of the state. Kheri district of the state was leading district in terms of production as well as in area under sugarcane crop. Among top 20 district of sugarcane crop in Uttar Pradesh 13 district are from western Uttar Pradesh. Among all districts of Uttar Pradesh. Shahjahanpur district ranks 16 in terms of production of sugarcane and 12 in terms of area under sugarcane crop. Shamli is the leading district,with 843 quintal per hectare production, as far as average yield of sugarcane is concerned which is followed by Meerut and Muzaffarnagar with 832 and 828.5 quintal per hectare yield respectively. Shahjahanpur district has also high yield i.e. 745 quintal per hectare.

Table 1: Area, Production and Yield of Major Sugarcane Producing Districts in Uttar Pradesh 2016-17

\begin{tabular}{ccccc}
\hline $\begin{array}{c}\text { S1. } \\
\text { No. }\end{array}$ & Districts & $\begin{array}{c}\text { Area (000' } \\
\text { hect.) }\end{array}$ & $\begin{array}{c}\text { Production } \\
\text { (000' tones) }\end{array}$ & $\begin{array}{c}\text { Yield (qt/ } \\
\text { hect.) }\end{array}$ \\
\hline 1 & Kheri & 261.0 & 17697.8 & 719.8 \\
2 & Bijnor & 202.0 & 16100.5 & 784.0 \\
3 & Muzaffarnagar & 165.1 & 14270.0 & 828.6 \\
4 & Sitapur & 146.5 & 9790.0 & 709.3 \\
5 & Merrut & 129.3 & 10937.4 & 832.3 \\
6 & Saharanpur & 121.2 & 9634.4 & 701.9 \\
7 & Bareilly & 87.8 & 6561.8 & 691.5 \\
8 & Amroha & 77.8 & 5719.7 & 740.3 \\
9 & Bagpat & 76.4 & 5718.9 & 771.3 \\
10 & Shamli & 61.7 & 53505 & 843.4 \\
11 & Pilibhit & 65.7 & 4757.8 & 701.3 \\
12 & Gonda & 71.7 & 4693.9 & 644.4
\end{tabular}




\begin{tabular}{lclll}
13 & Kushinagar & 77.9 & 4689.9 & 669.0 \\
14 & Bulandshahar & 51.5 & 3528.1 & 770.5 \\
15 & Moradabad & 44.7 & 3257.1 & 695.0 \\
16 & Shahjahanpur & 64.9 & 2970.1 & 745.9 \\
17 & Hapur & 36.4 & 2856.9 & 785.6 \\
18 & Basti & 40.7 & 2294.6 & 653.5 \\
19 & Balrampr & 44.5 & 2379.8 & 541.7 \\
20 & Hardoi & 38.7 & 2361.6 & 690.0 \\
\hline
\end{tabular}

Source: Indiastat.com

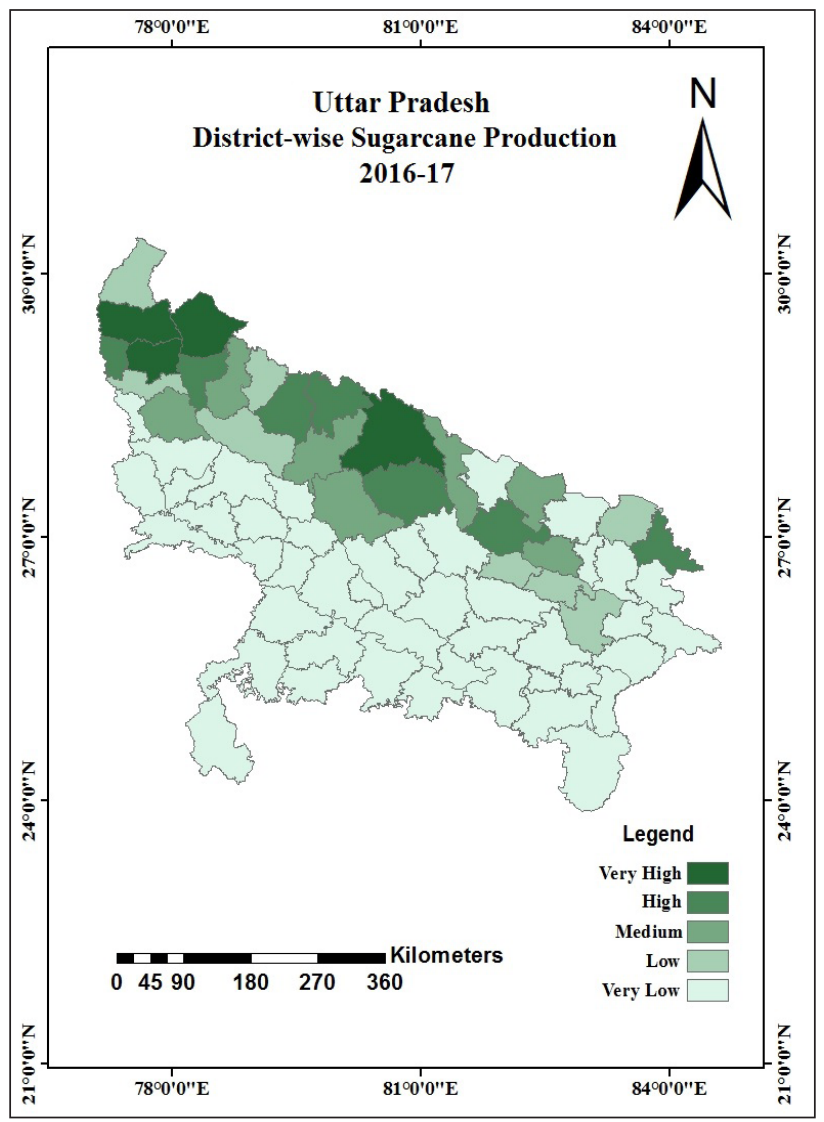

Fig. 2: Major Sugarcane Producing Districts in Uttar Pradesh (2016-17)

Table 2 and Fig. 3 shows the Compound Annual Growth Rate of sugarcane Production of India, Uttar Pradesh and Shahjahanpur district for the year 1997-98 and 2016-17. The table vividly showing that during the last twenty years the production of the crop has increased but the rate of growth is very slow in all the cases. The CAGR of production of sugarcane for national level is just 0.45 percent and it is still lower in case of state level while the CAGR of the district is only 0.25 percent between the points of time that is from 1997-98 to 2016-17.

In general, the slow growth rate in the production of sugarcane may be attributed to the factors like fluctuating area under the crop, low yield and price risk. In the western Uttar Pradesh, besides these factors, sugarcane crop face stiff competition with other favourable crops like potato and wheat.

Table 2: Compound Annual Growth Rate (CAGR) of Sugarcane Production in India, Uttar Pradesh and Shahjahanpur (1997-98 and 2016-17)

\begin{tabular}{cccc}
\hline \multirow{2}{*}{ Years } & \multicolumn{3}{c}{ Production in ‘000’ tones } \\
\cline { 2 - 4 } & India & Uttar Pradesh & Shahjahanpur \\
\hline $1997-98$ & 279535 & 129266 & 2832 \\
$2016-17$ & 306069 & 140169 & 2976 \\
CAGR & +0.45 & +0.41 & +0.25 \\
\hline
\end{tabular}

Source: Calculated By the authors, data obtained from Indiastat. com, 2018.

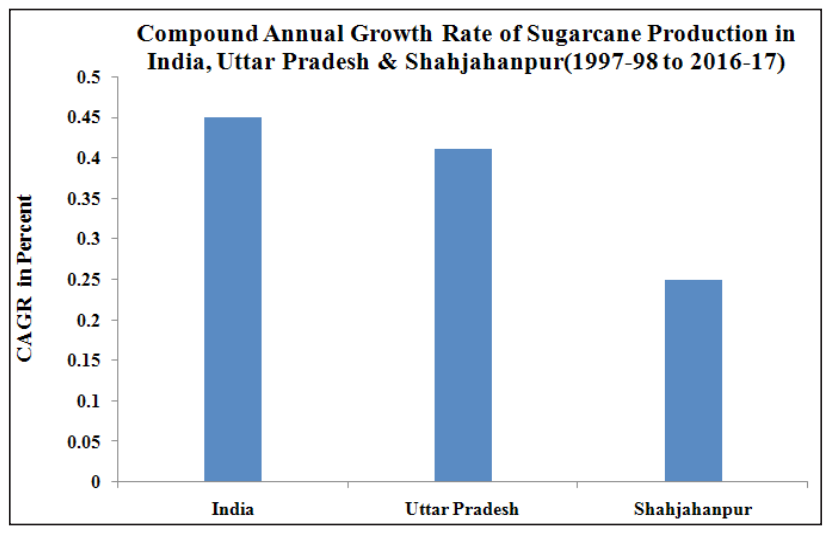

Fig. 3: Compound Annual Growth Rate of Sugarcane Production in India, Uttar Pradesh \& Shahjahanpur (1997-98 to 2016-17)

\section{Production of Sugarcane in Shahjahanpur District}

The following table and figure show the production of sugarcane from 1997-98 to 2016-17. The figure shows that there is an uneven trend of sugarcane production in district during the study period (19972017). This uneven trend is associated with the uncertain monsoon and some time weak monsoon, the changing government's policies especially the Minimum Support Price (MSP) of sugarcane and instability in the area under production of sugarcane in the study area.

A substantial increase in the production of sugarcane crop can be noticed during the year 2005-06. During this period the production increased from 2328 thousand tonnes to 2960 thousand tonnes between 2004-05 and 2005-06. It may be attributed to not only enhancement in the productivity of the crop but area under the sugarcane crop significantly increased. 
Perhaps, the most significant development took place in year 2004-05 was the change in political power at the centre which might have encouraged the Ganna Kisan to grow sugarcane again.

Table 3: Year-wise Sugarcane Production of Shahjahanpur District (1997-98-to 2016-17)

\begin{tabular}{cccc}
\hline Years & $\begin{array}{c}\text { Production } \text { (000' }^{\prime} \\
\text { tones) }\end{array}$ & Years & $\begin{array}{c}\text { Production } \\
\text { (000' tones) }\end{array}$ \\
\hline $1997-98$ & 2832 & $2007-08$ & 2002 \\
$1998-99$ & 2876 & $2008-09$ & 2088 \\
$1999-00$ & 2966 & $2009-10$ & 2142 \\
$2000-01$ & 2648 & $2010-11$ & 2124 \\
$2001-02$ & 2482 & $2011-12$ & 2300 \\
$2002-03$ & 2656 & $2012-13$ & 2307 \\
$2003-04$ & 2467 & $2013-14$ & 2330 \\
$2004-05$ & 2328 & $2014-15$ & 4385 \\
$2005-06$ & 2960 & $2015-16$ & 3975 \\
$2006-07$ & 2145 & $2016-17$ & 2970 \\
\hline
\end{tabular}

Source: Ministry of Agriculture \& Farmers Welfare, Government of India, 2018.

The history of sugarcane production in the district took another swift turn when production of sugarcane reached its peak in 2014-15. In comparison to 2013-14, there has been rapid increase in production of sugarcane from 2330 thousand tonnes to 4380 thousand tonnes in 2014-15, it was almost doubled between 2013-14 and 2014-15, that is only a difference of one agricultural session.

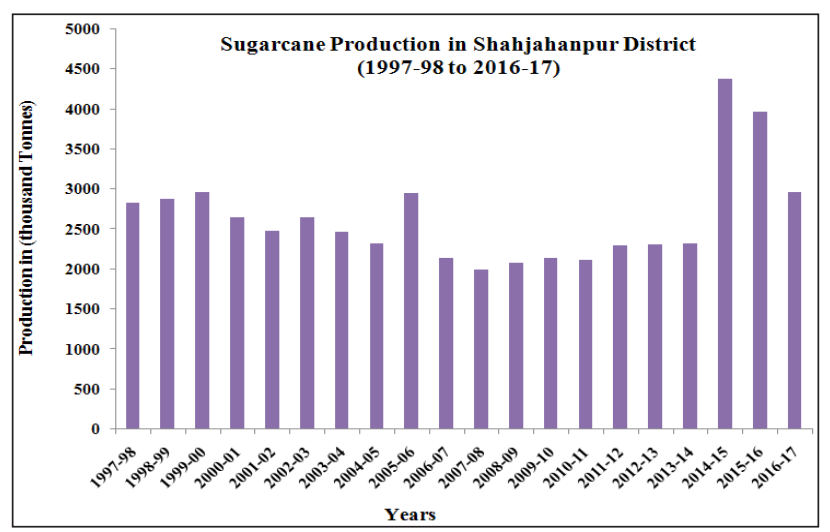

Fig. 4:Year-wise Sugarcane Production of Shahjahanpur District (1997-98-to 2016-17)

This phenomenal increase was in fact a cumulative effect of a number of measures taken by central and respective state governments. Firstly, after 2010-11, the minimum support price (MSP) replaced by more viable support price of sugarcane i.e. fare and remunerative price (FRP) and thus so called MSP has been stabilized up to certain level which boosted the sugarcane cultivation. And from 2012-13 to 201617 the FRP for sugarcane crop increased from ₹ 170 per quintal to ₹ 230 per quintal. This increment has given a new way to farmers to grow sugarcane crop. Moreover, the SAP(state advisory price) launched by some states including Uttar Pradesh, during the period, gave an added advantage to cane farmers which enhanced higher area under sugarcane production.

Table 4: Year-wise Area under Sugarcane Cultivation in Shahjahanpur District (1997-98 to 2016-17)

\begin{tabular}{cccc}
\hline Years & $\begin{array}{c}\text { Area in } \\
\text { Hectare }\end{array}$ & Years & $\begin{array}{c}\text { Area in } \\
\text { Hectare }\end{array}$ \\
\hline $1997-98$ & 46691 & $2007-08$ & 37866 \\
$1998-99$ & 49925 & $2008-09$ & 39590 \\
$1999-00$ & 52941 & $2009-10$ & 37566 \\
$2000-01$ & 51148 & $2010-11$ & 37712 \\
$2001-02$ & 48261 & $2011-12$ & 38877 \\
$2002-03$ & 51226 & $2012-13$ & 37577 \\
$2003-04$ & 45650 & $2013-14$ & 38270 \\
$2004-05$ & 38905 & $2014-15$ & 64909 \\
$2005-06$ & 41182 & $2015-16$ & 64909 \\
$2006-07$ & 37701 & $2016-17$ & 64909 \\
\hline
\end{tabular}

Source: Sankhyakiya Patrika, 2018.

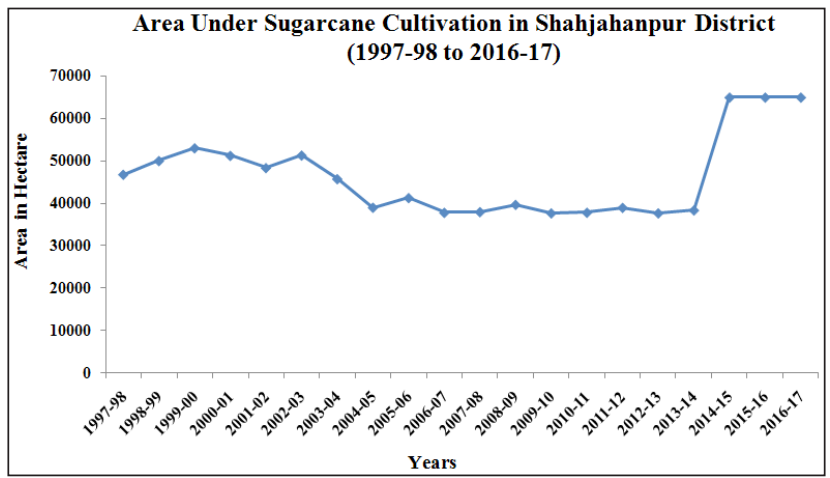

Fig. 5: Year-wise Area under Sugarcane Cultivation in Shahjahanpur District (1997-98 to 2016-17)

The above figure shows that there is an uneven trend in area under sugarcane in the district during the study period (1997-2017). The decline in area under sugarcane was due to poor government's pricing policy for sugarcane crop so, consequently farmers had moved away from sugarcane farming and engaged to grow another crops. Higher remunerative prices (market price) of other crops 
like potato in the previous years also have an effect to the choice of crop to the farmers. Farmers generally choose to grow crops that has higher remunerative price of crop. After 2013-14, there has been sharp increase in area under sugarcane cultivation in the district. The area increased to 64909 hectares from 37577 hectares during 2012-13 and 2016-17. The reasons for this unprecedented increase have already been discussed in the preceding paragraph.

Here it is important to note that during 2008-09 to 2012-13, the area under sugarcane was declining but the production was increasing in the district; this is mainly because of substantial increase in the productivity of sugarcane during the said period.

Table 5: Sugarcane Yield in India, Uttar Pradesh and Shahjahanpur (1997-98 to 2016-17)

\begin{tabular}{cccc}
\hline \multirow{2}{*}{ Years } & \multicolumn{3}{c}{ Yield (Quintal/Hectare) } \\
\cline { 2 - 4 } & India & Uttar Pradesh & Shahjahanpur \\
\hline $1997-98$ & 711.0 & 651.0 & 606.7 \\
$1998-99$ & 712.0 & 590.3 & 576.8 \\
$1999-00$ & 709.3 & 574.0 & 560.3 \\
$2000-01$ & 685.8 & 549.2 & 517.7 \\
$2001-02$ & 736.1 & 579.8 & 514.5 \\
$2002-03$ & 635.8 & 562.8 & 518.6 \\
$2003-04$ & 539.8 & 557.1 & 516.4 \\
$2004-05$ & 647.5 & 608.0 & 598.6 \\
$2005-06$ & 669.2 & 584.1 & 593.8 \\
$2006-07$ & 690.2 & 598.5 & 569.1 \\
$2007-08$ & 688.7 & 572.2 & 528.8 \\
$2008-09$ & 645.5 & 524.6 & 527.5 \\
$2009-10$ & 700.2 & 591.5 & 570.3 \\
$2010-11$ & 700.9 & 567.7 & 563.2 \\
$2011-12$ & 716.6 & 595.5 & 591.7 \\
$2012-13$ & 682.5 & 624.6 & 614.0 \\
$2013-14$ & 705.2 & 637.7 & 609.0 \\
$2014-15$ & 715.1 & 658.2 & 675.3 \\
$2015-16$ & 707.2 & 670.2 & 671.2 \\
$2016-17$ & 690.0 & 690.0 & 745.9 \\
\hline
\end{tabular}

Source: Sankhyakiya Patrika, 2018.

Table 5 demonstrates the trend of sugarcane yield of twenty years period of India, for Uttar Pradesh as well as for the Shahjahanpur District. Like production and area under the sugarcane crop, the data also revealing similar trend - unstable productivity, especially for the country as whole. This hierarchical comparison (country, state and district) of sugarcane yield shows a relative trend during the whole study period. It is evident from the figure 6 that in the year when the India records the higher yield, Uttar Pradesh as well as Shahjahanpur District also registered the higher yield and vice versa. Moreover, from the table it may be pointed out that the productivity of sugarcane has not recorded any remarkable variations as far as country as a whole is concerned except in two point of time. In 2003-04, the yield has gone down to less than 540 quintal per hectare while the highest yield (736 quintal per hectare) was recorded just two year back in the year 2001-02 during the whole study period.

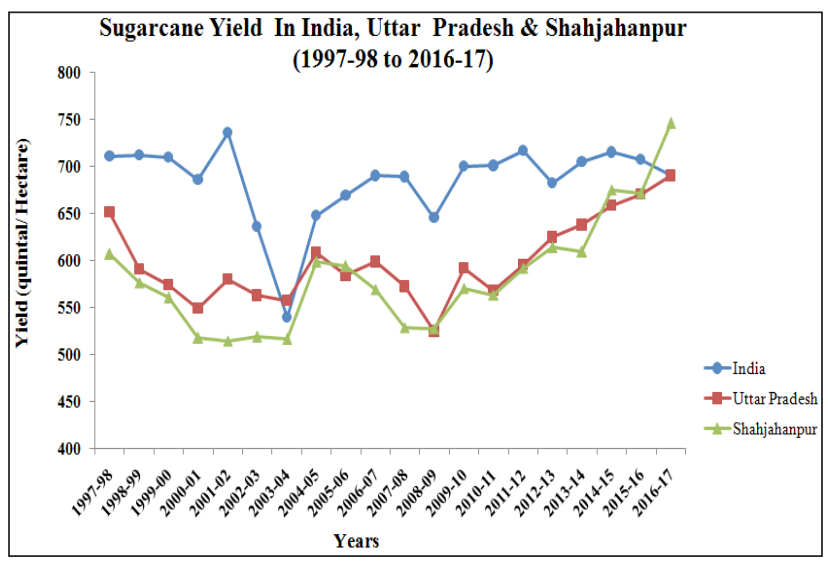

Fig. 6: Sugarcane Yield in India, Uttar Pradesh \& Shahjahanpur (1997-98 to 2016-17)

While analyzing the sugarcane yield in state of Uttar Pradesh as a whole, it has been noticed that the yield in the late nineties was higher, and then it declined in the middle of study period and again soared in the recent years. The highest yield of the crop was recorded in the year of 2016-17 i.e. 690 quintal per hectare, contrary to it; the lowest (525 quintal per hectare) was registered in the year 2008-09.

In addition to this, Shahjahanpur district has its own trend of the sugarcane productivity. It has more fluctuation in the sugarcane yield because of local weather and marketing conditions prevailing in the district. Sugarcane yield in the Shahjahanpur district is generally showing an increasing trends, except a few years when the yield was slightly declined. The above figure also revealed that the Shahjahanpur district made a sturdy stride as far as productivity is concerned and recorded steep growth during last fifteen years (2001-2016). During this period the productivity increased from less than 515 to more than 745 quintal per hectare. 


\section{Block-wise Analysis}

The table 6 shows block level area under sugarcane cultivation. The table also analyzed the compound annual growth of area under the crop for period of twenty years (1997 to 2017). There is a positive trend of growth in most of the blocks while few blocks recorded negative growth as well. This comparative analysis of two different periods helps us to understand the spatio-temporal variations in the area under sugarcane cultivation in the district. From the table it may be inferred that the total area was more than 46 thousand hectares under sugarcane cultivation in the year of 1997-98. The area under sugarcane cultivation was enhanced with the support of improved marketing facilities and better rural road for the transportation of bulky product. Subsequently, sugarcane cultivation sprawled over about 65 thousand hectares of land in the year of 2016-17. Hence, the growth (CAGR) of the sugarcane cultivated area between 1997-98 and 2016-17 was recorded as +1.66 .

Table 6: Block-wise Area under Sugarcane Cultivation in Shahjahanpur District, 2016-17

\begin{tabular}{ccccc}
\hline Sl. & Blocks & $\begin{array}{c}\text { Area in } \\
\text { Hectare } \\
\text { No. }\end{array}$ & $\begin{array}{c}\text { Area in } \\
\text { Hectare }\end{array}$ & CAGR \\
\hline 1 & Banda & 3770 & 4911 & +1.33 \\
2 & Khutar & 5881 & 6223 & +0.28 \\
3 & Powayan & 4371 & 5514 & +1.16 \\
4 & Sindhauli & 3368 & 2819 & $-\mathbf{0 . 8 9}$ \\
5 & Katra & 4418 & 4418 & 0 \\
6 & Jatipur & 1512 & 6238 & +7.34 \\
7 & Tilhar & 5415 & 3488 & $-\mathbf{2 . 1 8}$ \\
8 & Nighoi & 3326 & 5583 & +2.62 \\
9 & Kant & 3604 & 4762 & +1.40 \\
10 & Dedrol & 3645 & 8555 & +4.36 \\
11 & Bhawal khera & 6198 & 2321 & -4.79 \\
12 & Kalan & - & 2363 & - \\
13 & Mirzapur & - & 2345 & - \\
14 & Jalalabad & 705 & 2938 & +7.40 \\
15 & Madnapur & - & 2422 & - \\
\hline Total & & 46691 & $\mathbf{6 4 9 0 9}$ & $+\mathbf{1 . 6 6}$ \\
\hline & & & & \\
\hline 04 & & - & & \\
\hline
\end{tabular}

Source: Calculated by authors, data obtained from Sankhyakiya Patrika, 2018.

However, the block-wise analysis shows that Jatipur, Dedrol and Jalalabad blocks were recorded increasing trend of CAGR during the study period, on the other hand, the Sindhauli and Bhawal Kehra blocks shows the negative trend. Thus, from the above analysis, it can be concluded that the area under sugarcane cultivation is increasing with a steady rate in the district, although, some blocks had negative growth in the sugarcane cultivated area due to various causes like preference of paddy and wheat crops rather than sugarcane.

Crop concentration means the variations in the density of any crop in a given region at a given point of time. Crop concentration pattern is mainly to differentiate the areas of high and low density of individual crop in the different parts of the region and to determine regional dominance of a crop. The concentration of a crop in an area largely depends on its moisture, terrain, temperature, and other pedagogical conditions. It has a tendency to have high concentration in the areas of ideal agro climatic conditions and the density declines as the geographical conditions become less conducive (Husain, 1996).

Table 7: Block-wise Sugarcane Concentration in Shahjahanpur, 2016-17

\begin{tabular}{cccccc}
\hline $\begin{array}{c}\text { S1. } \\
\text { No. }\end{array}$ & Blocks & $\begin{array}{c}\text { Sugarcane } \\
\text { concentra- No. } \\
\text { tion }\end{array}$ & Blocks & $\begin{array}{c}\text { Sugarcane } \\
\text { concentra- } \\
\text { tion }\end{array}$ \\
\hline 1 & Banda & 0.76 & 9. & Kant & 1.26 \\
2 & Khutar & 1.08 & 10. & Dedrol & 2.39 \\
3 & Powayan & 1.26 & 11. & Bhawal & 0.58 \\
& & & & khera & \\
4 & Sindhauli & 0.60 & 12. & Kalan & 0.56 \\
5 & Khudaganj & 0.98 & 13. & Mirzapur & 0.69 \\
7 & Katra & Jatipur & 1.78 & 14. Jalalabad & 0.59 \\
7 & Tilhar & 0.99 & 15. & Madnapur & 0.54 \\
8 & Nighoi & 1.49 & & & \\
\hline
\end{tabular}

Source: Calculated by authors, data obtained from Sankhyakiya Patrika, 2018.

There are 15 blocks in Shahjahanpur district, and the above table shows the sugarcane concentration in all the blocks. The blocks were categorised into three groups according to the sugarcane concentration i.e., High, Medium and Low. Values from 0.54 to 1.16 shows the low concentration of sugarcane which includes the blocks namely Kalan, Mirzapur, Jalalabad, Madnapur, Bhawal Khera, Tilhar, Sindhauli, Katra, Banda and Khutar. Values from 1.17 to 1.77 shows the medium concentration 
AESRA

of sugarcane crop which includes the blocks Kanth, Nighoi and Powayan. And the High concentration value ranges from 1.78 to 2.39 which includes the Jatipur and Dedrolblocks.

The blockwise sugarcane concentration map (Fig. 7) also incorporates the location of six major sugar industries of the district. The map explicitly indicates that there is some definite relation between location of sugar industries and sugarcane concentration. The Dadrol block is surrounded by a number of sugar industries and thus have high concentration while the blocks namely Khutar, Sindhauli, Khudaganj, Kalan, Madnapur, Mirzapur etc have either no sugar industries or far away from the industries and consequently low concentration of sugarcane.

It is mater of fact that sucrose content of the cane goes on decreasing as days passes away after harvest. So the number of sugar indutries and distance from the field to the industries determine the sugarcane concentration in a region. Betterconnectivity and quick and afordable mode of transportation also facilitates in getteing better FRP of cane and thus encourages the cane farmers to stick with sugarcane.

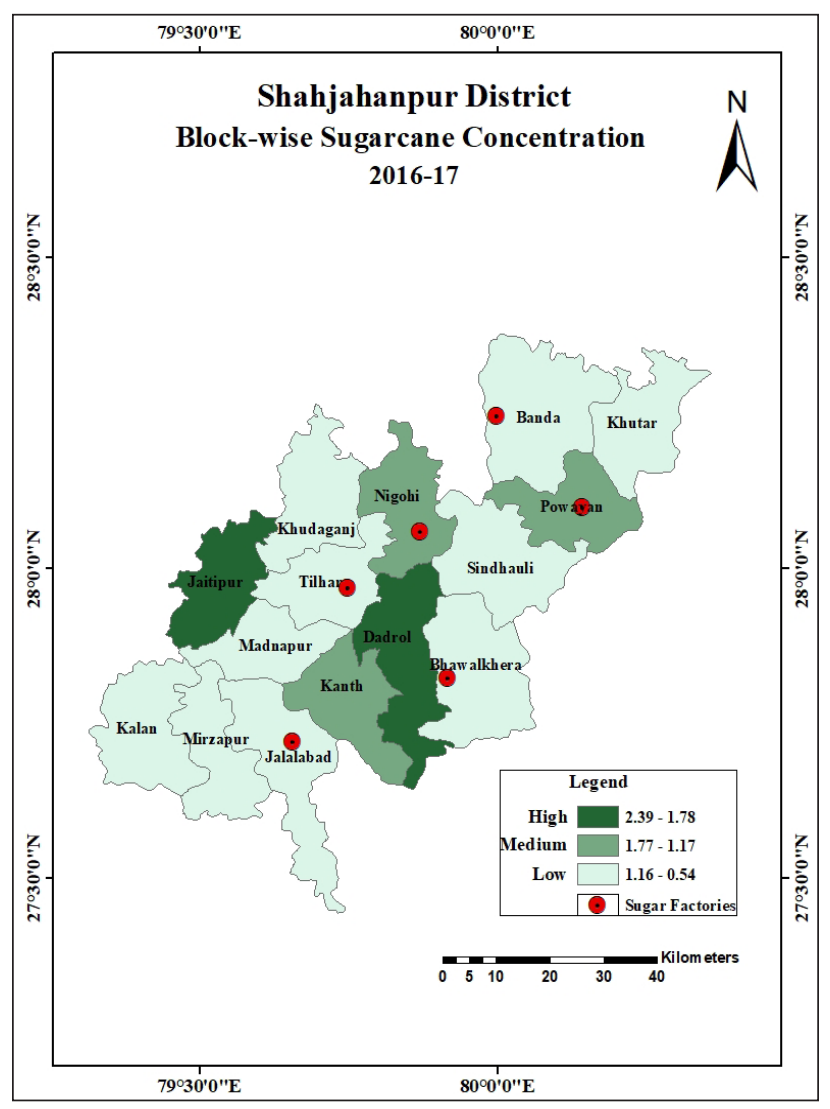

Fig. 7: Block-wise Sugarcane Concentration, Shahjahanpur District, 2016-17

\section{CONCLUSION}

It is evident from the study that there are fluctuations in the production of sugarcane in district, and no uniform pattern of growth in area under sugarcane is observed. From the study it is found that the rate of growth of sugarcane production in the district is very low as compared to state and national average. From 1997-98 to 2016-17 the compound annual growth rate(CAGR) of sugarcane production in the district was only 0.25 percent while it was 0.45 percent and 0.40 percent for India and Uttar Pradesh respectively.

Since, sugarcane is one of the most politically sensitive commodities, a small step in favour of Ganna kisan results in bigger changes in the cropping pattern in favour of the sugarcane. The introduction of FRP in 2011-12 has a cumulative effect on cultivation of sugarcane.

The experimental observation revealed that due to shortage of labour in the peak period, cost of harvesting increasing and the total cost of cultivation is increasing at an alarming rate. Sugarcane purchase price extended by the sugar factories is not sufficient as compared to the cost of production. Under these circumstances, Ganna kisan are searching for a way out to migrate to other crops. Another important reason for low production and low productivity is the unpredictable monsoon conditions.

Sugarcane is one of the important cash crops which occupy about 10 percent of the gross cropped area of the district and the stabilization of production of the crop is the pressing need for the district. In this regard, a favourable government for longer period can do the magic.

Although, the district experienced the substantial increase in the productivity of sugarcane yet the task is incomplete. There is ample evidence that the productivity of the crop can further enhanced as the district is far behind in terms productivity as far as top twenty sugarcane producing districts of Uttar Pradesh is concerned. Therefore, Ganna kisan needs to be motivated to use the improved technologies such as crop rotation, balanced use of organic and inorganic fertilizers, micronutrients, proper irrigation management etc.

At governmental level, crop concerned weather forecasting should be done and the acquired 
information of weather and monsoon should be provided to the farmers. Government must frame strong policies for crop procurement. These initiatives would enable the scope and increase the production of sugarcane in the district.

\section{REFERENCES}

Census of India 2011. District handbook of Shahjahanpur, Primary Census Abstract, Uttar Pradesh.

Chopart, J.L., Azeved, M.C.B. and Marion, D. 2010. Sugarcane root system depth in three different countries, International Society of Sugarcane Technology, 27.

Gaikwad, C. and Jadhav, S. 2017. Challenges Faced by Sugarcane Mills and Farmers in India. $7^{\text {th }}$ Internatinational Conference on Science, Technology and Management, Guru Govind Singh Polythenic Nasik (India).

Gohain, N. and Singh, S. 2018. An Analysis of Problems and Constraints Faced by Farmers in Marketing of Agricultural Produce in Punjab, Economic Affairs, 63(3): 671-678.

Husain, M. 1983. Systematic Agriculture Geography, Rawat Publication, Jaipur.

Kishore, N., Gayathri, D.,Venkatesh, J., Rajeswari, V., Sangeeta B and Chandrika, A. 2017. Present Mechanization Status in Sugarcane-A Review. International Journal of Agriculture Science, 9(22): 4247-4253.

Krishnakant, Tripathi, S.P. and Meena, M. 2015. Cost of cultivation of sugarcane crop in Meerut district of Uttar Pradesh. International Journal of Forestry and Crop Improvement, 6(1): 41-48.

Krishnamoorthy, 2017. A study of Sugarcane Production in India, International Journal of Advanced Research in Botany, 3: 13-17.

Kshirsagar, K.G. 2008. Organic Sugarcane Farming for Enhancing Farmers' Income and Reducing the Degradation of Land and Water Resource in Maharashtra, Indian Journal of Agricultural Economy, 63(3).

Kumar, A. and Singh, R. 2017. Risk analysis in sugarcane Production: Evidences from Uttar Pradesh and Maharashtra states of India, International Journal of Current Microbiology and Applied Science, 6(9): 1211-1216.

Makadia, J.J., Mistry H.H. and Kuthe S.B. 2017. Impact of soil health card on fertilizer Consumption and yield of Sugarcane and Kharif Paddy in Gujrat State, Economic Affairs, 62(1): 61-66.

Murali, P. and Raghupati, B. 2012. Labour Scarcity and Selective Mechanization of Sugarcane Agriculture in Tamil Nadu, India. Sugar Tech., 14(3): 223-228.

Pushpa and Shrivastav, S.K. 2014. Yield gap analysis and the determinants of yield gap in major crops in eastern region of Uttar Pradesh. Economic Affairs, DOI: 10.5958/09764666.2014.00039.4
Rama, R.I.V.Y. 2012. Efficiency, yield gap and constraints analysis in irrigated vis-a-vis rainfed sugarcane in north coastal zone of Andhra Pradesh. Agricultural Economics Research Review, 25(1):167-171.

Ramarao, I.V.Y.2011. An Economic Appraisal of Manufacturing and Marketing of Jaggery in Andhra Pradesh state, India. Sugar Tech., 13(3): 236-244.

Rangnekar, D.V. 1988. Integration of sugarcane and milk production in western India. FAO Animal Health and Production Paper No.72, 176-187.

Rout, R.K., Mishra R.K., Bar, N. and Mondal, D. 2013. Farmers perception on Contract Framing of Sugarcane in Orissa: A Village Level Study,Economic Affairs, 58(4): 367-37.

Saravanan, A. 2016. An analysis of cost and returns of sugarcane production in Erode district of Tamil Nadu. Indian Journal of Economics and Development, 4(8).

Shrikrishna and Mahajan, S. 2013. Measuring Financial Health: A Comparative Study of Co-operative Sugar Factories, ETHOS., 6: 23-30.

Shrivastav, A.K., Solomon, S. and Sawnani, A. 2011. Sugarcane Cultivation and Sugar Industry in India: Historical Perspectives, Sugar Tech., 13(4): 266-270.

Sinha, A.K. and Singh, S.K. 2019. Economics of Potato Production in Northern Hills of Chhattisgarh, Economic Affairs, 64(1): 01-07.

Upreti, P. and Singh, A. 2017 An Economic Analysis of Sugarcane Cultivation and its productivity in Major Sugar Producing States of Uttar Pradesh and Maharashtra, Economic Affairs, 62(4): 711-718.

Vasanta, K. 2013. Impact of climate change on Wheat and Rice production: An analysis. Economic Affairs, 58(2): 89-95.

Yadav, R.L. and Solomon, S. 2006. Potential of developing sugarcane and by products-based industries in India, Sugar Tech, 8: 104-111.

Yasmeen et al. 2017. Factors responsible for the performance of cooperative sugar factories in North- Eastern Karnataka, Economic Affairs, 64(2): 225-230.

Yasmeen, Patil, S.S., Hiremath, G.M. and Ananda, N. 2018. Economics of Sugar Production of Cooperative Sugar factories in North Eastern Karnataka, Economic Affairs, 63(1): 159-164.

Zaidi, N.H. and Munir, A. 2014. Participation of Women in Sugarcane Farming System-A Case Study of Bijnor District (Western Uttar Pradesh). Economic Affairs, 59(3): 449-457.

Zaho, D. and Yang, R. L. 2015. Climate change and sugarcane production potential impact and mitigation strategies, International journal of Agronomy, Vol. 15 article ID (547386). 
